\title{
Analisis Quietus Politik Terhadap Upaya Pemerintah Menangani Wabah Covid-19 Pasca Deklarasi Public Health Emergency Of International Concern (PHEIC)
}

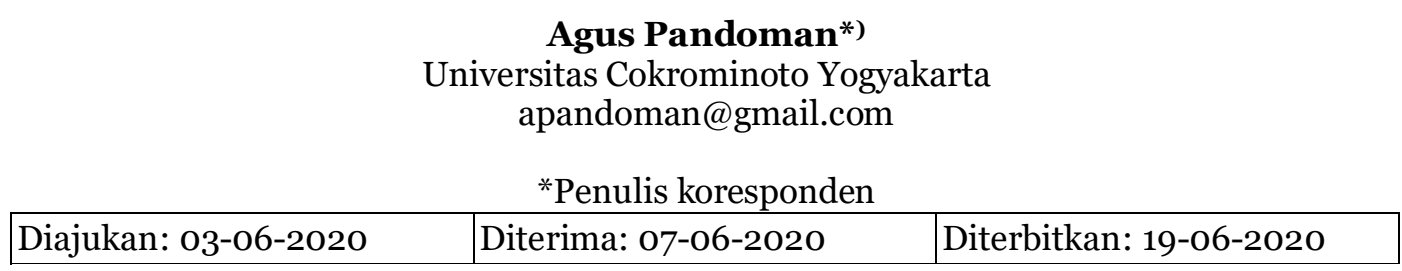

\begin{abstract}
This study examines what the Indonesian government has done after the declaration of the COVID-19 outbreak as PHEIC by WHO in terms of regulations and regulations. This research legal philosophical in the analysis of quietus politic theory concludes that the element of urgency in the determination of health emergencies is non-negotiable in its handling.
\end{abstract}

Keywords: quietus politic, COVID-19, Indonesian government, PHEIC

\begin{abstract}
Abstrak: Penelitian ini mengkaji apa saja yang telah dilakukan pemerintah Indonesia pasca deklarasi wabah COVID-19 sebagai PHEIC oleh WHO dari sisi regulasi dan peraturan. Penelitian legal filosofis dalam analisis teori Quietus politik ini menyimpulkan unsur kesegeraan dalam penetapan kedaruratan kesehatan tak bisa ditawar lagi dalam penanganannya.
\end{abstract}

Kata Kunci: Quietus Politik, COVID-19, pemerintah Indonesia, PHEIC

\section{A. Pendahuluan}

Coronavirus Disease (Covid-19) telah menyebar dimana-mana. Semua tingkat kehidupan dunia telah terkena dampaknya hingga local dalam kuantitas korban tewas yang banyak. Situasi demikian telah memaksa Badan Kesehatan internasioal (WHO) menetapkannya sebagai PHEIC pada 30 Januari 2020 didasarkan pada International Health Regulation (IHR) tahun 2005. ${ }^{1}$

Semua Negara anggota WHO harus mentaati dan melaksanakan IHR. Sistemnya yang mengikat secara hukum bertujuan melindungi

1 Prianter Jaya Hairi, "Implikasi Hukum Pembatasan Sosial Berskala Besar Terkait Pencegahan COVID-19," Info Singkat Bidang Hukum 12, no. April (2020): 1-6. 
semua orang dari penyebaran penyakit global. ${ }^{2}$ Kewaspadaaan dunia telah ditingkatkan namun masih kewalahan karena seluruh aktivitas kehidupan keseharian manusia merasakan kerugian dari COVID-19. Negara Kesatuan Republik Indonesia (NKRI) tak terkecuali dari sebarannya yang telah meluas secara drastis dalam hitungan hari.

Pemerintah RI terlibat langsung menangani dan mengawasi kehidupan warga dari sebaran yang liar tak terkendali di wilayahnya. Dalam bahasa Hasibuan dan Azhari, serta Telaumbanua, harus ada jaminan perlindungan yang pasti dari pemerintah melalui peraturan dan undang-undang karena keberadaannya sebagai Negara hokum.3 Apabila tidak dilakukan, kepercayaan masyarakat terhadap pemerintah bisa mengalami kerugian. 4 Salah satunya upaya pemerintah ialah penetapan kebijakan lock down selama 14 hari guna antisipasi penularan wabah global tersebut.5 Bentuk ini menjadi dianggap oleh Setiawan sebagai penerapan perundangan yang mengatur karantina kesehatan. ${ }^{6}$ Aspek kehidupan spiritual keagamaan juga terkena pembatasan dalam peraturan pemerintah Maqasid al-Shariah, melahirkan pilihan putusan antara pemeliharaan agama atau jiwa. 7

Pemerintah memang tidak bisa melepaskan diri dari amanat pemenuhan hak warga bahkan di bidang keagamaan dalam antisipasi

2 R. Habibi et al., "Do Not Violate the International Health Regulations during the COVID-19 Outbreak," The Lancet 395, no. 10225 (2020): 664-666; Adam KamradtScott, "The International Health Regulations (2005)," International Organizations Law Review 16, no. 2 (2019): 242-271.

3 Rezky Panji Perdana Martua Hasibuan and Anisa Ashari, “Optimasi Peran Negara Menghadapi Pandemi Corona Virus Disease 2019 Dalam Perspektif Hukum Tata Negara Darurat," Salam: Jurnal Sosial dan Budaya Syar-i 7, no. 7 (2020); Dalinama Telaumbanua, "Urgensi Pembentukan Aturan Terkait Pencegahan Covid-19 Di Indonesia," Qalamuna - Jurnal Pendidikan, Sosial, dan Agama 12, no. 1 (2020): 59-70.

4 Bima Jati and Gilang Rizki Aji Putra, "Optimalisasi Upaya Pemerintah Dalam Mengatasi Pandemi Covid 19 Sebagai Bentuk Pemenuhan Hak Warga Negara,” SALAM: Jurnal Sosial dan Budaya Syar-i 7, no. 5 (2020): 473-484.

5 Nur Rohim Yunus and Annissa Rezki, "Kebijakan Pemberlakuan Lockdown Sebagai Antisipasi Penyebaran Corona Virus Covid-19," SALAM: Jurnal Sosial dan Budaya Syar-i 7, no. 3 (2020): 227-238.

6 Yusufa Ibnu Sina Setiawan, "Penetapan Karantina Wilayah Menurut Pandangan Legal Positivisme Dalam Rangka Pencegahan Dan Pemberantasan Pandemi Coronavirus Disease (Covid)-19" (2020).

7 Hudzaifah Achmad Qotadah, "Covid-19: Tinjauan Maqasid Al-Shariah Terhadap Penangguhan Pelaksanaan Ibadah Shalat Di Tempat Ibadah (Hifdz Al-Nafs Lebih Utama Dari Hifdz Al-Din?)," SALAM: Jurnal Sosial dan Budaya Syar-i 7, no. 7 (2020). 
sebaran Covid-19. Bagi Indonesia sebagai sebagai negara hokum dengan warga negara mayoritas muslim, ${ }^{8}$ penanganan Covid-19 dengan penerapan ide sekuler yang memisahkan secara berseberangan antara negara dari agama sangat sulit diberlakukan.

Pandangan Agama dan Negara selalu berkaitan telah dimulai sejak awal kebangkitan negara Islam di Madinah. ${ }^{9}$ Hal itu telah terpateri dalam benak sebagian besar warga muslim. Karena itu, kehadiran beberapa aspek hokum Islam di Indonesia telah diterima secara etika sosial maupun perundangan. ${ }^{10}$ Pemerintah turut serta dalam pengaturan Wakaf karena posisinya sebagai pemegang amanat hak publik. ${ }^{11}$ Bahkan keterlibatannya hingga penanganan wilayah social melalui Kementrian Agama, termasuk pencegahan perkawinan usia dini. ${ }^{12}$ Sekarang muncul usulan kelembagaan khusus bagi pemerintah dalam akitivitas makro perbankan syariah. ${ }^{13}$ Maka keterlibatan pemerintah dalam pengaturan ibadah bersama dalam mengantisipasi Covid-19 tidak perlu diperdebatkan berlarut-larut. Kesungguhan pemerintah menjadi wajib dalam kondisi sekarang, baik secara fikih maupun hokum perundangan.

\section{B. Metode Penelitian}

Penelitian mengkaji obyek yang sama dengan Hairi dan Telaumbanua yang mengamati alur legislasi hukum peraturan yang ditetapkan pemerintah RI setelah deklarasi WHO tentang wabah Covid-19. Kajiannya yang berbeda dengan mendasarkan pada teori Quietus Politik (QP). Karena berkaitan berkaitan legislasi perundangan yang tertulis sebelum kebijakan new normal diberlakukan oleh pemerintah, maka

8 M. Nurkholis Al Amin, "Mohammed Abid Jabiri, Reformasi Hukum Islam Dan Pembaruan Pengetahuan," Ulumuddin: Jurnal Ilmu-ilmu Keislaman 9, no. 2 (2020): 133-152.

9 M. Nurkholis Al Amin and Nurjidin Nurjidin, "Hubungan Negara-Ummah Dalam Hukum Indonesia Dan Islam," Ulumuddin: Jurnal Ilmu-ilmu Keislaman 7, no. 2 (2017): 103-116.

10 Sembodo, "Dari Khilafah."

${ }_{11}$ Nurjidin Nurjidin and F Setiawan Santoso, "Peran Nazhir Wakaf Dalam Perundang-Undangan Indonesia," Ulumuddin: Jurnal Ilmu-ilmu Keislaman 6, no. 2 (2016): 100-111.

${ }_{12}$ Ahmad Wafiq and F. Setiawan Santoso, "Upaya Yuridis Dan Sosiologis Kantor Urusan Agama Dalam Pencegahan Pernikahan Usia Dini," Ulumuddin: Jurnal Ilmu-ilmu Keislaman 7, no. 1 (2017): 17-30.

13 Agus Pandoman, "Urgensi Berdirinya Bank Sentral Syariah Di Indonesia," Ulumuddin: Jurnal Ilmu-ilmu Keislaman 9, no. 2 (2019): 153-170. 
penelitian kepustakaan secara kualitatif bisa memudahkan penggalian dan analisis data untuk perumusan kesimpulan. Tinjauan tentang QP menjadi awal dari pembahasan kemudian digunakan sebagai dasar analisis sebelum ditutup dengan kesimpulan.

\section{Quietus Politic, Selayang Pandang}

Kata Quietus sudah dipakai pada Abad Pertengahan sekitar tahun 1500-an di Eropa. Saat wilayah itu dalam masa Renaissance dimana penindasan-penindasan dari manusia terhadap sesamanya manusia lain atas nama agama sedang dalam kondisi puncak.14 $\mathrm{Di}$ Inggris frase Latinnya -quietus est- yang bermakna harfiah -dia berhenti- sebagai nama surat perintah pembebasan yang membebaskan seorang baron atau ksatria dari pembayaran pajak ksatria kepada raja. Setelah berlaku umum, Ungkapan itu kemudian disingkat menjadi quietus untuk arti penghentian hutang apa pun-. William Shakespeare menjadi pengguna pertama sebagai metafora untuk makna -pemutusan kehidupan- dalam karyanya, Hamlet. "When he himself might his quietus make /with a bare bobkin.” Di abad ke-19 kata digunakan untuk frase yang berarti lebih cenderung -diam- daripada -berhenti- yaitu, "put the quietus on". Maka dalam quietus ada tiga arti; penyelesaian akhir per hutang; penghapusan dari aktivitas, khususnya: kematian; dan sesuatu yang menenangkan atau mendiamkan atau menekan sehingga terdiam di saat perayaan atau keramaian. 15

Pandoman menjelaskan makna kematian dalam quietus, yaitu; kematian orang atau kematian ekonomi.16 Kehidupan manusia sudah pasti berujung pada kematian. Saat mencapainya, manusia sering menggunakan strategi yang identik dengan politik. kekuasaan dan pemerintah juga semakna dalam istilah politik. Itulah alasan dari Mason yang mengatakan politik itu lebih condong ke seni dari pada ilmu sehingga tidak bisa dijelaskan secara sempurna. ${ }^{17}$

${ }^{14}$ Ahmad Tafsir, Filsafat Umum (Bandung: Remaja Rosdakarya, 2015).

15 “Quietus," Merriam-Webster.Com Dictionary, n.d.

${ }^{16}$ Agus Pandoman, Quietus Politik (yogyakarta: UII Press, 2016).

${ }_{17}$ Fred Isjwara, Pengantar Ilmu Politik (Malang: Bina Cipta, 1982), 16. 
Konteks politik sebagai kekuasaan menjurus ke apa-apa untuk mendapatkan apa-apa. Tindakan yang dilakukan untuk mendapatkan apaapa adalah perwujudan dari pikiran untuk menguasai materi. Kekuasaan kemudian berbentuk rekognisi kesadaran manusia terhadap materi dalam prinsip, tidak ada seorang pun berbuat lebih baik tanpa membuat orang lain lebih buruk. Hal ini berbeda dengan pendapat yang mengatakan bahwa tindakan bisa dipisahkan dari kepentingan politik. Dengan demikian ada kemungkinan untuk beristirahat, memindahkan tindakan kepada kondisi ketenangan. ${ }^{18}$

Poltik QP selanjutnya telah menjadi jantung kehidupan. Politik selalu bergerak dan menggerakkan manusia. Seluruh kehidupannya adalah politik, hidup dan matinya tergantung pada politik. Eksistensi demikian itu nyata dan realistis. Sehingga penampakan dalam kehidupan sekarang ini adalah sebuah lintasan antara kerja manual dan mental serta berada dalam lintasan distorsi antara politik dan kematian. ${ }^{19}$

Garis batas inilah yang memisahkan kesadaran terbagi dalam dua sistem. Gagasan utama dalam teori QP, mencoba menerangkan bagaimana cara kerja sebuah kesadaran terhadap pemenuhan kebutuhan hidup, yang dalam keadaan darurat dimana hasil keputusannya tidak akan bisa menyelamatkan semuanya "Tiada seorangpun dapat berbuat lebih baik, tanpa membuat orang lain lebih buruk.”

\section{Quietus Politic dan Peraturan tentang Covid-19}

Pasca penetapan Covid-19 sebagai PHIEC pada 30 Januari 2020 dan sebelum keluarnya peraturan PSBB di RI ada rentang waktu yang panjang untuk penanganannya. Hairi mencatat keaktifan pemerintah RI sebatas 4 tindakan. Pertama, penanganan terhadap orang telah tertular Covid-19. Kedua, imbauan pembatasan sosial (social distancing) dan pemeliharaan kebersihan kepada masyarakat sebagai pencegahan dari sebaran meluas. Untuk peribadatan, Kementerian Agama telah

18 Paul J. Griffiths, "The Quietus Of Political Interest," Common Knowledge 15, no. 1 (2009): 7-22.

19 Pandoman, Quietus Politik. 
mengeluarkan Surat Edaran pendukung. ${ }^{20}$ Ketiga, pembatasan komoditas impor dari negara sumber penularan yang diatur oleh Menteri Perdagangan. ${ }^{21}$ Terakhir, penutupan jalur penerbangan dari dan ke negara lain. ${ }^{22}$

NKRI tidak menetapkan hukum kedaruratan kesehatan masyarakat serta aturan pelaksananya sesegera mungkin. ${ }^{23}$ Kecepatan respon terhadap wabah global sangat disarankan dalam IHR 2005, Hitungannya bahkan sampai hitungan jam. ${ }^{24}$ Pasal 43 dari hokum pengikat internasional itu juga mengatur tindakan yang dapat diterapkan oleh tiap negara untuk menangani risiko kesehatan masyarakat terhadap tindakantindakan yang didukung oleh ilmu pengetahuan, sepadan dengan risiko yang terlibat, merujuk kepada hak-hak kemanusiaan. ${ }^{25}$

Pengaturan secepatnya tentang kedaruratan kesehatan pun sudah diatur dalam Undang-Undang Nomor 6 Tahun 2018 Tentang Kekarantinaan Kesehatan (UUKK) sebagai aturan lanjutan dari IHR 2005 di NKRI. Kejadian kesehatan masyarakat yang bersifat luar biasa dengan ditandai penyebaran penyakit menular dan/atau kejadian yang disebabkan oleh radiasi nuklir, pencemaran biologi, kontaminasi kimia, bioterorisme, dan pangan yang menimbulkan bahaya kesehatan dan berpotensi menyebar lintas wilayah atau lintas negara. ${ }^{26}$

Presiden baru menandatangani Keputusan Presiden tentang Penetapan Kedaruratan Kesehatan Masyarakat terkait Covid-19 di 31 Maret. ${ }^{27}$ Langkah itu kemudian ditindaklanjuti penetapan PSBB sebagai

20 Menteri Agama RI, Surat Edaran Menteri Agama Nomor 1 Tahun 2020 Tentang Pelaksanaan Protokol Penanganan Covid-19 Pada Rumah Ibadah, 2020.

${ }^{21}$ Menteri Perdagangan RI, Peraturan Menteri Perdagangan Nomor 10 Tahun 2020 Tentang Larangan Sementara Impor Binatang Hidup Dari Republik Rakyat Tiongkok, 2020.

22 Hairi, "Implikasi Hukum."

23 Telaumbanua, "Urgensi Pembentukan."

24 Lihat pasal Pasal 12(3) dan 43(5), World Health Organization, International Health Regulations (2005) Third Edition, 2016.

25 Habibi et al., "Do Not"; Kamradt-Scott, "The International."

${ }^{26}$ Republik Indonesia, Undang-Undang Nomor 6 Tahun 2018 Tentang Kekarantinaan Kesehatan, 2018.

27 Presiden RI, Keputusan Presiden Republik Indonesia Nomor 11 Tahun 2020 Penetapan Kedaruratan Kesehatan Masyarakat Corona Virus Disease 2019 (COVID19), 2020. 
Percepatan Penanganan Covid-19. ${ }^{28}$ Pada 4 April 2020, Menteri Kesehatan baru menerbitkan aturan pelaksana berupa Pedoman (PSBB). ${ }^{29}$

Konteks politik penanganan dalam belitan Covid-19 pasca PHIEC merupakan kekuasaan untuk menghentikan terhadap penyebaran wabah. Kekuasaan dalam kondisi darurat adalah rekognisi kesadaran penguasa terhadap kebijakan mengapa dalam penciptaan kebijakan yang bermuara pada suatu pilihan dalam prinsip, "Tidak ada seorang pun yang dapat berbuat lebih baik tanpa membuat orang lain lebih buruk.”

Detail substansi UUKK merupakan implementasi dari teori QP, yaitu menerapkan kesadaran persuasif maksimal yaitu dengan menganjurkan untuk melakukan kebijakan memilih kematian ekonomi, dari pada memilih kematian orang. Pilihan pemerintah dalam kondisi darurat yang demikian bisa disandingkan dengan fatwa Ibn Hazm dalam hokum Islam agar pemerintah membebaskan orang miskin yang telah mengambil hak kebutuhan sandang pangan dan papan dengan kekerasan hingga kematian.30 Artinya, pemerintah harus mengutamakan kehidupan warganya. Negara bisa mengesampingkan pertimbangan lainnya agar hak warga itu bisa terpenuhi di masa darurat itu.

Penerapan karantina dalam pertimbangan pemerintah pusat, memang sangatlah dilematis. Sebagaimana di perintahkan dalam pasal 55 UUKK, "Selama dalam karantina wilayah kebutuhan dasar orang dan makanan hewan ternak yang berada di wilayah karantina menjadi tanggung jawab pemerintah pusat." Tetapi pelaksanaannya bisa melibatkan pihak lain. pada ayat 2 diatur bahwa tanggung jawab pemerintah pusat dalam menyelenggarakan karantina wilayah dilakukan dengan melibatkan pemerintah daerah dan pihak yang terkait. Inilah kesadaran persuasif maksimal karena lebih baik mengorbankan ekonomi di wilayah tertentu dari pada menyebar kematian di seluruh negara.

\footnotetext{
${ }^{28}$ Republik Indonesia, Peraturan Pemerintah Nomor 21 Tahun 2020 Pembatasan Sosial Berskala Besar Dalam Rangka Percepatan Penanganan Coronavirus Disease 2019/COVID-19, n.d.

29 Menteri Kesehatan RI, Peraturan Menteri Kesehatan Nomor 9 Tahun 2020 Tentang Pedoman Pembatasan Sosial Berskala Besar (PSBB), n.d.

${ }_{30}$ F. Setiawan Santoso, "Peran Bait Mal Dalam Jaminan Sosial Di Era Fikih Klasik," Ulumuddin: Jurnal Ilmu-ilmu Keislaman 2, no. 2 (2017): 117-136.
} 
Kesadaran yang perlu dipertahankan dalam politik kedaruratan adalah sesuatu yang dapat melindungi dirinya dengan mempertahankan kehidupan. Kondisi darurat menjangkau waktu -pembiaran- yang sedemikian rupa hingga dalam waktu dimana tiada seorang dapat berbuat lebih baik tanpa membuat orang lain lebih buruk. Realitas demikian sesungguhnya menunjukkan jantung kehidupan adalah politik dengan gagasan (berpikir) dalam lintasan distorsi antara politik dan kematian (orang atau ekonomi).

Keberadaan manusia senantiasa digerakkan dengan pikiran untuk menjamin pemenuhan hak hidup secara pribadi serta memberikan kesempatan untuk kemakmuran. Sementara interaksi pikiran dalam belitan wabah Corona adalah interaksi coveat, kecurigaan jangan-jangan orang itu telah tertular atau termasuk dalam pemantauan.

Kesadaran sesungguhnya adalah pikiran. Menurut Descartes jika hal-hal yang menjadi pertimbangan akal dalam suatu keputusan tertuju pada politik, maka pemikiran itu sedang berada dalam kesadaran res cogitans, kesadaran politik dimana mental (jiwa) menyatu dengan pemikiran, tahap ini menjadi pertaruhan orang mengembangkan pemikiran mengenai pengambilan keputusan adalah sesuatu yang disadarinya sebagai pertimbangan hal-hal untuk menangani permasalahan seperti wabah Covid-19. Apakah wabah ini mengakibatkan kategori keadaan darurat sipil atau kesehatan yang membawa kematian yang massif. Kategori seperti itu sudah disajikan dalam UUKK .

Dalam konteks teori QP, Pandoman menyebutnya kesadaran persuasif minimal.31 Artinya Cogitans masih memiliki mental (jiwa). Sesuatu pemikiran yang membangkitkan substansi rasio berbuat lebih baik, tanpa membuat orang lain lebih buruk, sebagai pemilihan rasio terhadap pemenuhan kebutuhan hidup sehat secara jasmani dan ekonomi.

Substansi rasio QP tidak berhenti disini, namun bergerak pada perluasan pemenuhan tubuh dengan pemenuhan materi. Kondisi yang disebut sebagai res extansa. Tindakan persuasifnya telah menjangkau

${ }^{31}$ Pandoman, Quietus Politik. 
melebihi cogintans, yang menjelma menjadi berpikir untuk menjawab, "Bagaimana jika terjangkit wabah Covid-19." Pilihannya pun telah tersedia dalam wujud UUKK.

Berangkat dari asumsi QP bahwa pikiran sesungguhnya adalah kesadaran, Eksistensi kehidupan (kita ada) karena kita berpikir (thinking being). Berpikir memungkinkan akal mengenali cara mental bekerja, yang menetapkan nilai yang lebih tinggi terhadap dua kesadaran persuasif: Pertama disebut sebagai kesadaran persuasif minimal (disingkat: Pm) dan Kedua dikenal sebagai kesadaran persuasif maksimal (disingkat: Px).

Implementasi dari kedua persuasif perlu dijabarkan lebih lanjut. Pm adalah Cogitans yang masih memiliki mental dimana rasio berbuat lebih baik, tanpa membuat orang lain lebih buruk sebagai pilihan saat pemenuhan kebutuhan hidup. Itulah pemenuhan kebutuhan hidup dalam ukuran Pm. Misalnya kebutuhan hidup sehat adalah keadaan sehat, baik secara fisik, mental, spritual maupun sosial yang memungkinkan setiap orang untuk hidup produktif secara sosial dan ekonomis sudah dapat dipenuhi oleh semua orang. Dalam pengertian Pm, cara kerja rasio manual dalam keadaan normal. Di kondisi darurat, meskipun substansinya berbeda, maka manual tetap bisa bekerja.

Px adalah res extansa. ${ }^{32}$ Persuasifnya adalah tidak lagi ke dalam jiwa dirinya, namun pikirannya telah menjangkau melebihi res cogitans, yang menjelma menjadi berpikir untuk memiliki gagasan,"bagaimana jika“. Bekerjanya mental, sebagai hasil dari pemikiran tentang perlindungan dan penanggulangan. keluarannya adalah rekayasa pemikiran penanggulangan antara kematian orang atau ekonomi terhadap bencana yang melanda dirinya (negara). Menggunakan gagasan menyimpang dari substansinya, apakah outputnya (Px) menciptakan perlindungan.

32 Ibid. 


\section{E. Penutup}

Ucapan syukur atas pemerintah NKRI telah melakukan tindakan penting dalam peraturan-peraturan yang diterbitkan untuk mengantisipasi penyebaran Covid-19. Semuanya berbeda dengan kebijakan yang dikeluarkan pasca penetapannya sebagai PHEIC dari WHO. Hukum baru itu telah bisa diselaraskan dengan UUKK. Pilihan itu telah memastikan dan melindungi segala tindakan pemenuhan hak warga untuk mempertahankan hidup daripada pemulihan ekonomi. Hal yang dipandang perlu diutamakan dalam teori QP dalam kondisi darurat wabah Covid-19 sekarang ini.

\section{Daftar Pustaka}

Al Amin, M. Nurkholis. "Mohammed Abid Jabiri, Reformasi Hukum Islam Dan Pembaruan Pengetahuan.” Ulumuddin: Jurnal Ilmu-ilmu Keislaman 9, no. 2 (2020): 133-152.

Al Amin, M. Nurkholis, and Nurjidin Nurjidin. "Hubungan NegaraUmmah Dalam Hukum Indonesia Dan Islam." Ulumuddin: Jurnal Ilmu-ilmu Keislaman 7, no. 2 (2017): 103-116.

Griffiths, Paul J. "The Quietus Of Political Interest." Common Knowledge 15, no. 1 (2009): 7-22.

Habibi, R., G. L. Burci, T. C. de Campos, D. Chirwa, M. Cinà, S. Dagron, and S. Negri. "Do Not Violate the International Health Regulations during the Covid-19 Outbreak." The Lancet 395, no. 10225 (2020): 664-666.

Hairi, Prianter Jaya. "Implikasi Hukum Pembatasan Sosial Berskala Besar Terkait Pencegahan Covid-19." Info Singkat Bidang Hukum 12, no. April (2020): 1-6.

Hasibuan, Rezky Panji Perdana Martua, and Anisa Ashari. "Optimasi Peran Negara Menghadapi Pandemi Corona Virus Disease 2019 Dalam Perspektif Hukum Tata Negara Darurat.” Salam: Jurnal Sosial dan Budaya Syar-i 7, no. 7 (2020).

Isjwara, Fred. Pengantar Ilmu Politik. Malang: Bina Cipta, 1982.

Jati, Bima, and Gilang Rizki Aji Putra. "Optimalisasi Upaya Pemerintah Dalam Mengatasi Pandemi Covid 19 Sebagai Bentuk Pemenuhan Hak Warga Negara.” SALAM: Jurnal Sosial dan Budaya Syar-i 7, no. 5 (2020): 473-484.

Kamradt-Scott, Adam. "The International Health Regulations (2005)." International Organizations Law Review 16, no. 2 (2019): 242271.

Menteri Agama RI. Surat Edaran Menteri Agama Nomor 1 Tahun 2020 Tentang Pelaksanaan Protokol Penanganan Covid-19 Pada Rumah Ibadah, 2020.

Menteri Kesehatan RI. Peraturan Menteri Kesehatan Nomor 9 Tahun 2020 Tentang Pedoman Pembatasan Sosial Berskala Besar 
(PSBB), n.d.

Menteri Perdagangan RI. Peraturan Menteri Perdagangan Nomor 10 Tahun 2020 Tentang Larangan Sementara Impor Binatang Hidup Dari Republik Rakyat Tiongkok, 2020.

Nurjidin, Nurjidin, and F Setiawan Santoso. "Peran Nazhir Wakaf Dalam Perundang-Undangan Indonesia.” Ulumuddin: Jurnal Ilmu-ilmu Keislaman 6, no. 2 (2016): 100-111.

Pandoman, Agus. Quietus Politik. yogyakarta: UII Press, 2016.

- - . "Urgensi Berdirinya Bank Sentral Syariah Di Indonesia." Ulumuddin: Jurnal Ilmu-ilmu Keislaman 9, no. 2 (2019): 153-170.

Presiden RI. Keputusan Presiden Republik Indonesia Nomor 11 Tahun 2020 Penetapan Kedaruratan Kesehatan Masyarakat Corona Virus Disease 2019 (Covid-19), 2020.

Qotadah, Hudzaifah Achmad. "Covid-19: Tinjauan Maqasid Al-Shariah Terhadap Penangguhan Pelaksanaan Ibadah Shalat Di Tempat Ibadah (Hifdz Al-Nafs Lebih Utama Dari Hifdz Al-Din?).” SALAM: Jurnal Sosial dan Budaya Syar-i 7, no. 7 (2020).

Republik Indonesia. Peraturan Pemerintah Nomor 21 Tahun 2020 Pembatasan Sosial Berskala Besar Dalam Rangka Percepatan Penanganan Coronavirus Disease 2019/Covid-19, n.d.

--C. Undang-Undang Nomor 6 Tahun 2018 Tentang Kekarantinaan Kesehatan, 2018.

Santoso, F. Setiawan. "Peran Bait Mal Dalam Jaminan Sosial Di Era Fikih Klasik." Ulumuddin: Jurnal Ilmu-ilmu Keislaman 2, no. 2 (2017): 117-136.

Sembodo, Cipto. "Dari Khilafah Ke Nation-States: Transformasi Hukum Islam Era Modern.” Ulumuddin: Jurnal Ilmu-ilmu Keislaman 6, no. 2 (2016): 136-150.

Setiawan, Yusufa Ibnu Sina. "Penetapan Karantina Wilayah Menurut Pandangan Legal Positivisme Dalam Rangka Pencegahan Dan Pemberantasan Pandemi Coronavirus Disease (Covid)-19" (2020).

Tafsir, Ahmad. Filsafat Umum. Bandung: Remaja Rosdakarya, 2015.

Telaumbanua, Dalinama. "Urgensi Pembentukan Aturan Terkait Pencegahan Covid-19 Di Indonesia." Qalamuna - Jurnal Pendidikan, Sosial, dan Agama 12, no. 1 (2020): 59-70.

Wafiq, Ahmad, and F. Setiawan Santoso. "Upaya Yuridis Dan Sosiologis Kantor Urusan Agama Dalam Pencegahan Pernikahan Usia Dini." Ulumuddin: Jurnal Ilmu-ilmu Keislaman 7, no. 1 (2017): 17-30.

World Health Organization. International Health Regulations (2005) Third Edition, 2016.

Yunus, Nur Rohim, and Annissa Rezki. "Kebijakan Pemberlakuan Lockdown Sebagai Antisipasi Penyebaran Corona Virus Covid-19." SALAM: Jurnal Sosial dan Budaya Syar-i 7, no. 3 (2020): 227238.

"Quietus.” Merriam-Webster.com Dictionary, n.d. 
Agus Pandoman 